\title{
Két téglaégető kemence Somogy megyéből
}

\author{
'MOLNÁR ISTVÁN \\ Rippl-Rónai Múzeum, H-7400 Kaposvár, Fő utca 10. \\ e-mail: molnaristvan74@yahoo.com
}

MoLnÁR, l.: Two brick kilns from Somogy county

Abstract: In my study I present two brick burning kilns found in Somogy county. In the kiln in Bódvica (dated to the turn of the $13-14^{\text {th }}$ centuries), bricks made to build the medieval church of the village. The kiln excavated near Lulla was likely to used during the $18-19^{\text {th }}$ centuries.

Keywords: brick kilns, middle ages, $13-14^{\text {th }}$ centuries, $18-19^{\text {th }}$ centuries

\section{Bevezetés}

Tanulmányomban két Somogy megyei téglaégető kemencét szeretnék röviden bemutatni, amelyek eltérő időszakban készültek, mégis sok közös vonást mutatnak. Bár az egyik erősen sérült, a másik pedig csak részben lett feltárva, úgy vélem értékes adatokkal bővítik a téglaégetőkkel kapcsolatos ismereteinket.

\section{A Nagyatád-bódvicai téglaégető kemence}

\section{A lelőhely és a feltárás}

Somogy megyében az első téglaégető kemencét 2002 júliusában, a ma már Nagyatádhoz tartozó Bódvica mellett találta Aradi Csilla. A középkori Boda falu templomának feltárása közben végzett terepbejárások során, a templomtól 100 méterre délnyugatra a szántásban tégladarabokat észleltek, majd a megnyitott kutatószelvényben egy téglaégető részletét tárták fel. ${ }^{1}$

Boda falu Belső-Somogy déli részén, Nagyatádtól délre feküdt (1. ábra 1.). A település első említése 1229ből való, temploma először 1333-ban, a pápai tizedjegyzékben szerepel. 1542-ben még említették plébánosát, a török alatt hol pusztaként, hol lakott helyként írtak róla. A 18. század elején a falu 1000 méterrel északabbra települt újjá. ${ }^{2}$

A templom jórészt elpusztult, csak alapozásának alsó 2-3 téglasora maradt meg. A rövid kutatás során sikerült tisztázni alaprajzát. A 10,7 méter hosszú kerektemplomnak 7,7 méter átmérőjü hajója és a diadalívtől 3,3 méter hosszú patkóíves szentélye volt. A szentélyhez, valamint a hajó nyugati oldalához, 2-2 db. 1,1×1,2 méteres támpillér csatlakozott, amelyek a templom többi részével egy időben épültek (2. ábra). A 110-130 centiméter széles alapozásnál használt 25-26×12-13 centiméter méretű téglákat agyagba fektették, azonban a téglák közét jobbára homokkal töltötték ki (3. ábra). Aradi Csilla a templomot a 13-14. század fordulójára keltezte. ${ }^{3}$ A korabeli falu a templom körül helyezkedett el.

\section{A téglaégetö kemence}

A kemence nyomai a szántásban látszottak, a felső részei elpusztultak. A rövid, a templom azonosítására koncentráló feltárás során nem bontották ki teljesen, de formáját így is sikerült nagyjából megállapítani.

A kemence délnyugati sarka - nyugati falának hosszabb szakasza a rajta lévő két tüzelőnyílással, déli falának és tǔzterének nagyobb darabja - lett feltárva (4-5. ábra). A nagyméretü, szögletes építményt az altalajba ásták. Függőleges oldalfalai 90-120 centiméter magasan megmaradtak, legalább ennyire földbe mélyedt. A kemence pontos méretét nem tudjuk megmondani. Ugyan csak a délnyugati sarkánál tárták fel az aljáig, de a nyugati falát északabbra is követték, így tudjuk, hogy 4,8 méter hosszú lehetett. Mivel a nyílások kevés kivétellel a hosszabbik oldalon szoktak elhelyezkedni, az objektum méretét 10-20 $\mathrm{m}^{2}$ közé tehetjük. Két 55-60 centiméteres ívelt fütőnyílás került feltárásra, a kemence feltételezhető mérete alapján összesen négy lehetett. A téglaégető alja és oldalai tapasztva voltak, utóbbiak kb. 10 centiméter vastagon átégtek. Az objektum munkagödre nem esett a szelvénybe.

1 Aradi Csillának ezúttal is megköszönöm az objektum publikálásának lehetőségét.

2 ARADI 2016, 107-108; JANKOVICH 1976, 14-15.

3 ARADI 2003; A keltezés a templom formai elemein és párhuzamain alapul. Alaprajzára legjobban hasonlító épületek a 13. században épültek. A körtemplom építésekor már támpilléreket használtak. 




1. ábra. A téglaégető kemencék lelöhelye: 1. Nagyatád-Bódvica, 2. Lulla-Büdösalja

A kemence alja egy szintben, egyenesen lett kialakítva, az ásáskor nem készítettek mélyebben futó tűzcsatornákat és magasabb padkákat. A padkákat így nem az altalajból alakították ki, hanem élére állított téglákból építették meg, amelyeket nyersen raktak ki és az égetéskor égtek keményre. A kemence déli falánál, a legdélebbi csatornától délre keskenyebb, a két csatorna között szélesebb volt a padka. Ez máshol, a hagyományos, altalajból kialakított padkáknál is megfigyelhető. A déli falnál lévő padka 26 centiméter, 1 téglasor széles volt. Az alsó sort észak-déli, a tűzcsatornákra merőleges irányú, élére állított téglákból rakták ki. A téglák nem szorosan álltak egymás mellett, köztük téglányi széles réseket hagytak. Az ezekre fektetett második sor már viszonylag szorosan egymás mellé tett téglákból állt. Az ellentétes irányban (nyugat-keletre) álló darabokból három fért el egymás mellett. A harmadik sorból csak egy, az alsó sorral egyforma, észak-déli állású maradt a nyugati falnál, így nem tudjuk ebben a sorban nagyobb közökkel vagy (ami valószínúbb) viszonylag szorosabban állították egymás mellé a téglákat (6-7. ábra). A két tűzcsatorna közötti padka 55-60 centiméter széles volt. Középen nyugatkeleti irányú téglákból állítottak egy sort, amihez két oldalról merőleges, észak-déli irányú, álló helyzetű téglákat raktak úgy, hogy köztük itt is téglányi közöket hagytak. A felsőbb sorokból itt sajnos semmi nem maradt (7.ábra). A padkákon még több sor magasan lehettek a téglák, a tűzcsatornák felett boltozatosan rakhatták fel ezeket.

\section{A kemence keltezése, párhuzamai}

A kemence korának megállapítása nem egyszerű feladat, hiszen ezek alakja, a kemenceégetés munkamódszere a legújabb korig nagy hasonlóságokat mutat. ${ }^{4} \mathrm{~A}$ kemence platniján archeomágneses mérést nem végeztek, datáló értékű leletanyag nem volt benne. A feltárásakor a felső szántott rétegben találtak késő középkori kerámiát. Ugyanakkor a belsejében talált téglák nagyon hasonlítanak a közeli templom alapozásában megtalált téglákra, más korabeli téglaépületet nem is ismerünk a környéken. A téglaégető használatát nagy biztonsággal a templom építéséhez köthetjük, így - annak datálását elfogadva - a 13-14. század fordulójára keltezhetjük.

4 JAKAB 2005; JAKAB 2007; VALTER 1989, 9-18. 
NYUGATI METSZETFAL

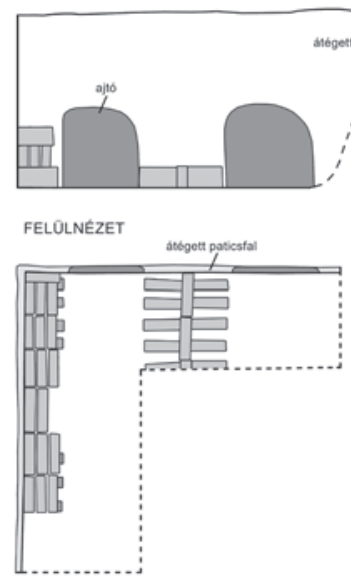

4. ábra. A téglaégető feltárt részének alaprajza
és nyugati falának metszetrajza

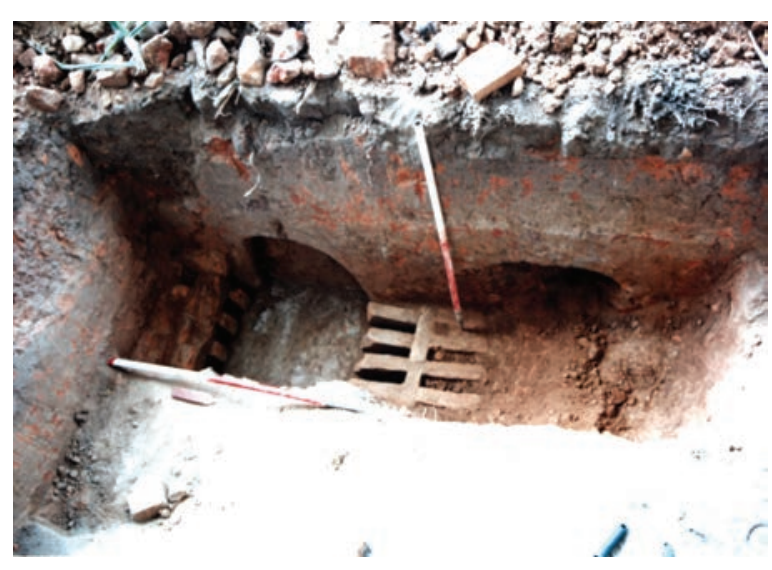

5. ábra. A bódvicai téglaégető kibontott része

A téglaégetőkkel kapcsolatos ismereteket Valter Ilona ${ }^{5}$ és Lőrinczy Gábor ${ }^{6}$ után Jakab Attila foglalta össze. ${ }^{7}$ 2011-ben 16 lelőhelyről 25 kemencét mutatott be, ami jól mutatja az objektumtípus viszonylagos ritkaságát. Bár a tanulmány megjelenése után is közöltek téglaégetőket, ${ }^{8}$ ismeretem szerint Somogy megyéből még nem publikáltak ilyen objektumot.

Amennyire a kemence formája rekonstruálható, legközelebbi párhuzamaiként egy-egy Dombóváron, Pakson és Hetényben talált téglaégetőt említhetünk. Dombóvár-Szigeterdőn, a korábban Rosner Gyula által már részben kibontott, de tévesen meghatározott objektumot Miklós Zsuzsa tárta fel és azonosította téglaégetőként. Az építmény szintén téglalap alakú, viszonylag mélyen földbe ásott. A mérete is hasonló, 520 centiméter a hosszabbik oldala, szintén 4 fütőnyílása volt. A két téglaégető között az a legnagyobb különbség, hogy a dombóvári kemencénél kialakították a fütőcsatornákat, ugyanakkor ezek igen sekélyek, 4-6 centiméteresek voltak, így önmagukban nem láthatták el funkciójukat. Miklós Zsuzsa is valószínűnek tartotta, hogy az égetés előtt téglával magasították a padkákat. A kemencét először feltáró Rosner Gyula a kemence belső oldalán egy sor élére állított (a beépítés után kiégő) téglát talált. Valószínűleg a padkák itt is a bódvicai kemencéhez hasonlóan lettek kialakítva és az alsó sor élére állított tégláit találták meg. Úgy vélem, nincs sok különbség a tűzcsatornák teljes hiánya, illetve néhány centiméteres mélysége között, hiszen mindkét esetben ugyanúgy szükség van valamilyen padka készítésére az égetés előtt. A téglaégetőt leletanyaga alapján Miklós Zsuzsa a 13. századra, 1272 előttre keltezte. ${ }^{9}$ Figyelemre méltó, hogy az ismert kemencék közül földrajzilag is ez van legközelebb, használatuk hasonló időszakra keltezhető. Míg Bódvicán egy falusi templomhoz, Dombóváron egy lakótorony építése céljából égették a téglákat.

Hasonló téglaégetőt tártak fel Ács Zsófia vezetésével Paks-Cseresznyés lelőhelyen is. A téglalap alakú, földbe ásott, bódvicainál hosszabb, 575×320 centiméteres kemencének szintén 4 fütőnyílása és 4 tüzelőcsatornája volt, ezek mérete a bódvicaihoz hasonló. Az 50 centiméter széles, alacsony padkák a beszámoló szerint csak pár centiméteresek voltak. A padkákon néhol megmaradtak az élükre állított téglák is, amelyek az egymás feletti sorokban merőleges irányban voltak. A közölt képen jól megfigyelhető hogy - a bódvicai kemencéhez hasonlóan - az alsó sorban a téglák nagyobb szünetekkel, míg a második sortól már szorosabban álltak egymás mellett. A lelőhelyen egy Árpád-kori templom maradványait is feltárták, a kemencében ennek építéséhez égették a téglákat. ${ }^{10}$

Hetény-Delihegyen Peter Romsauer két földbe ásott, téglalap lakú, három csatornás kemencét tárt fel. Az egyiknek viszonylag sekély padkái voltak, a másiknál - a Bódvicán talált téglaégetőhöz hasonlóan - nem voltak fütőcsatornák kialakítva. Míg a bódvicai kemencét 4 csatornásként rekonstruálhattuk, a 4,6×2 méteres hetényi kemence 3 csatornás volt. Sajnos a téglák felrakása ezen a kemencén nem volt rekonstruálható. ${ }^{11}$

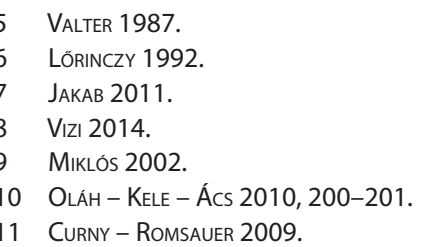


Jakab Attila a téglaégetők tipologizálása során a dombóvári, paksi és hetényi kemencéket a leggyakoribb, IV. típusba (földbemélyített kemencék állandó rostély nélkül) sorolta. ${ }^{12} \mathrm{~A}$ bódvicai kemence is ide sorolható, illetve az egyik hetényi kemencével együtt felfogható a csoport variánsának. A többi hasonló kemence készítésekor az altalajból magasabb padkákat alakítottak ki. ${ }^{13}$ Sajnos kevés kemencében maradtak meg a téglák, úgy tűnik ezek felrakásában is különbséget figyelhetünk meg. A magasabb padkával rendelkező bátaszéki, őriszentpéteri, békéscsabai valamint a hetényi első téglaégetőnél a padkákra tett téglák már az alsó sorban is viszonylag szorosan álltak egymás mellett, köztük csak kis rések maradtak. ${ }^{14} \mathrm{~A}$ bódvicai és a paksi kemence alsó - a padkákat helyettesítő - sora viszont ritkásan rakott, a téglák között nagyobb rések maradtak. Ennek okát feltehetően abban kereshetjük, hogy így a meleg levegő a téglák között jobban áramolhatott, mint a tömör agyagpadkák esetében.

\section{Lulla-büdösaljai téglaégető kemence}

\section{A lelöhely és a feltárás}

A második téglaégető kemence maradványait Lulla-Büdösalja lelőhelyen találtuk meg. Lulla település Somogy megye északkeleti részén, a Külső-somogyi dombságban, Tabtól északra helyezkedik el (1. ábra 2.).

A lelöhelyet 2010-ben és 2011-ben, a Balatonendréd és Lulla közötti új összekötő út építését megelőző régészeti feltárások során tártuk fel. 11251 m²-en 448 objektumot, több korszak (rézkor, bronzkor, kelta és római kor, középkor) objektumait sikerült kibontanunk és dokumentálnunk. ${ }^{15}$ Az objektumok többsége a kora Árpádkortól a késő középkorig volt keltezhető, a középkori Lulla faluhoz tartozott. A leletanyag teljes feldolgozásáig annyi állapítható meg, hogy az objektumok egy része nem datálható a 11. századnál későbbre, tehát már korai megtelepüléssel számolhatunk. Ekkor - hasonlóan a kelta és római időszakhoz - elsősorban a mélyen fekvő részekre települtek, míg a 13-14. században már inkább a magasabban lévő domboldalt lakták. A jelenség okát a talajvízszint emelkedésében kereshetjük. Az objektumok viszonylag sűrűn helyezkedtek el, többször metszették egymást. A számos gödör, cölöplyuk, árok mellett több külső kemence és kemencebokor, és egy földbemélyített alapárkos épület is feltárásra került.

A források igazolják a feltárás adatait, a település már a 11. században előfordul a forrásokban, temploma elöször 1264-ban szerepel. A török időkben egy darabig még említették, de a 17. század elejére pusztává vált. A 18. században 1,5-2 kilométerre északra jött létre Lullapuszta, majd a 20. századi telepítések során költözött vissza a falu délebbre, mai helyére, középkori elődéhez közel. ${ }^{16} \mathrm{~A}$ téglaégető kemence a lelőhely légmélyebben fekvő, patak melletti részéről, az Árpád-kori település legkorábbi objektumai mellől került elő.

\section{A téglaégetö kemence}

Sajnos a kemence jelentős része megsemmisült, eredeti méretére csak következtethetünk. Az északi és keleti részei teljesen elpusztultak, keleten a mélyebb tüzelöcsatornák ott is követhetők, ahol a sekélyebb padkák már nem látszanak. A maradványok olyan sekélyen voltak, hogy a délnyugati sarka kivételével a szántásnyomok is erősen „sávozták". A korabeli járószintet nem ismerjük, de feltételezhetjük, hogy a kemence nem volt túl mélyre ásva.

A kemence téglalap alakú volt, hossztengelye északkelet-délnyugati irányú volt, a szája északkeleten lehetett. A rövidebb oldala 542 centiméter hosszan maradt meg, ennél csak néhány centiméterrel lehetett hosszabb. A hosszabbik oldalfalát nagyjából 520 centiméter hosszan tudtuk követni, de a jobban földbemélyített fütőcsatornák a délnyugati faltól 625 centiméterre észlelhetők voltak, az objektum valamivel ennél is hosszabb lehetett. Nagyjából 550×650-660 centiméteres mérettel, 35-36 m²-es területtel számolhatunk. Az objektumnak $3 \mathrm{db}, 70$ centiméter széles, a hosszabbik oldallal párhuzamos, legalább 570 centiméter hosszú fütőcsatornája volt, amely alját és oldalát tapasztották. A kemencénél állandó rostély nyomát nem találtuk, a szélein 40 centiméter, a tủzcsatornák között 108 centiméteres, 20 centiméter magas tapasztott padkákat alakítottak ki (8-10.ábra).

A kemencét átmetszettük, a tapasztás alatt kb. 25 centiméter vastagon át voltak égve, a felső 8-10 centiméteres vörösre égett, kemény réteg alatt sötétszürke, majd vörös átégés volt. A tűzelőcsatornák alatt vékonyabb vörös réteg volt (9. ábra, 11. ábra). A padkákat nagyobb hőhatás érte mint a tǔzcsatornák alját. A középső és északi csatornájában téglatörmelékes, átégett, omladékos kevert réteg volt, a jobban megmaradt déliben törött és egész téglákat is találtunk (12-13. ábra).

12 JАKAB 2011, 140.

13 A padkák mérete Debrecenben 15-20cm, Hajdúszoboszlón 10-15 cm (JAKAB 2011, 137-138.), Öriszentpéteren 20 cm (VALTER 1989, 4.), Békéscsabán 20 cm (LőRINCZy 1992, 169.), Bátaszéken 28-30cm és 33 cm (Vızı 2014, 291, 294.) volt. A tiszalöki (LőRINCZY 1983, 158-161.), és a dömösi kemencéknek is magas padkája volt (GEREVICH 1983, 407-408.).

14 Vizı 2014, 310-318, 15-64. kép; VALTER 1987, 145, 6-9. kép; LőRINCZY 1992, 4. kép; CuRnY - RomSAUER 2009, 528, 4. kép

15 MoLnÁR - SiPos 2013. A feltáráson a Rippl-Rónai Múzeum munkatársai közül Molnár István, Sipos Carmen régészek, Varga Máté, Nyári Zsolt, Balla Krisztián, Cserép Tamás, Gál Zoltán és Stunya Péter vett részt.

16 Aradi 2016, 148; Nagy 2005. 
A kemencét körülárkolták, a nyesett felszíntől nagyjából 30 centiméterre lemélyülő, a kemence tüzelőcsatornáival megegyező mélységű, 1-1,3 méter széles árok vette körül az objektumot. Négyzet vagy téglalap alakú lehetett, a kemence oldalaitól 1,5-2 méterrel távolabb, azokkal megegyező állásban ásták ki. A keleti része ennek is megsemmisült. Az árok betöltését egy erősen égett, paticsos sáv osztotta ketté, a félig már betöltődött árokba feltehetően a kemence működése során keletkezett égéstermék került. Az északi részében egy ólomgolyót találtunk, egyéb leletanyaga nem volt (8. ábra, 10. ábra).

A téglaégető helyéhez közel csak az Árpád-kor korai szakaszában laktak, később magasabb területre költöztek, így a kemence és az azt körbefogó árok környékén nem volt a kora Árpád-kornál fiatalabb objektum. A magas talajvíz és egy, a területen futó vízér miatt a hely most sem alkalmas állandó megtelepülésre, a mai falu házai a vízen túli, szemben lévő dombon sorakoznak. Ugyanakkor a viszonylag sekélyen lemélyedő téglaégető számára megfelelő volt a terület.

Hasonló objektumok általában vízparton és gyakran a településtől távol kerülnek elő. A víz közelségét általában a munkafolyamat vízigényével és a szállítással magyarázzák. ${ }^{17}$ Esetünkben a vizet a Jaba-patak és a hozzá csatlakozó vízfolyás jelenti, amely ma már rendezett mederben folyik, de korábban szélesebb ártere volt, még a második katonai felmérésen is így van ábrázolva.

\section{A kemence párhuzamai, keltezése}

A kemencének jó párhuzamait találjuk a középkori anyagban. Jakab Attila tipológiája alapján - ahogy a bódvicai - ez is a leggyakoribb, IV. típusba (földbemélyített kemencék állandó rostély nélkül) sorolható. A hossztengellyel párhuzamos 3 csatornája alapján a IV/3/a típusba tartozik. Az ilyen kemencéket földbe mélyítették, állandó rostélyt nem alakítottak ki náluk, a kiégetendő téglák egy részét rakták fel olyan módon, hogy így funkcionáljanak. A falukat és padkájukat tapasztották, a legtöbbször 3 vagy 4 csatornájuk volt. A felszíni, tábori kemencék földbemélyített változataként jellemezhetőek. ${ }^{18}$

A lullai kemence eredeti pontos méretét nem tudjuk megmondani, maradványai alapján legalább 32-33 $\mathrm{m}^{2}$ lehetett. Méretbeli párhuzamként a békéscsabai, 14-16. századra, ${ }^{19}$ és az őriszentpéteri, 16. század elejére keltezett ${ }^{20}$ hasonló szerkezetű téglaégető említhető.

A téglaégetők datálási problémái jól illusztrálhatók a kemencén. A kemencét Árpád-kori objektumok között találtuk, akár ide is datálhatnánk. A kemence megszűnése utáni feltöltődésekor a korábbi objektumok kerámiája került bele, római és őskori töredékek mellett több Árpád-kori és kevés késő középkori kerámiát találtunk tüzelőcsatornáiban, ami alapján kezdetben késő középkorinak gondoltuk. ${ }^{21}$ Mérete alapján is elsősorban ide lenne keltezhető.


8. ábra. A lullai téglaégető kemence alaprajza

17 LÖRINCZY 1992, 179; JAKAB 2011, 144-145.

18 ЈАКАВ 2011, 140-142.

19 LÖRINCZY 1992, 167-171.

20 Valter 1987.

21 MOLNÁR - SIPOS 2013, 119. 
80. obj.



(A) (B)

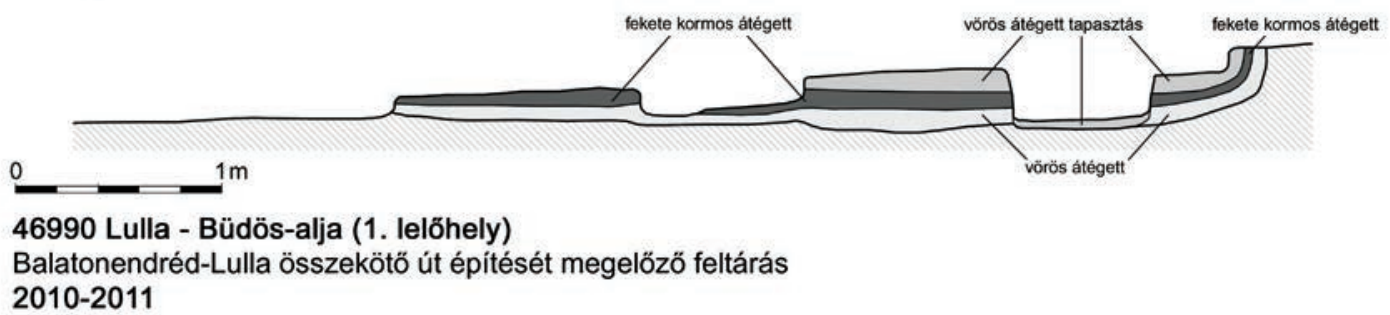

9. ábra. A lullai kemence metszetrajza

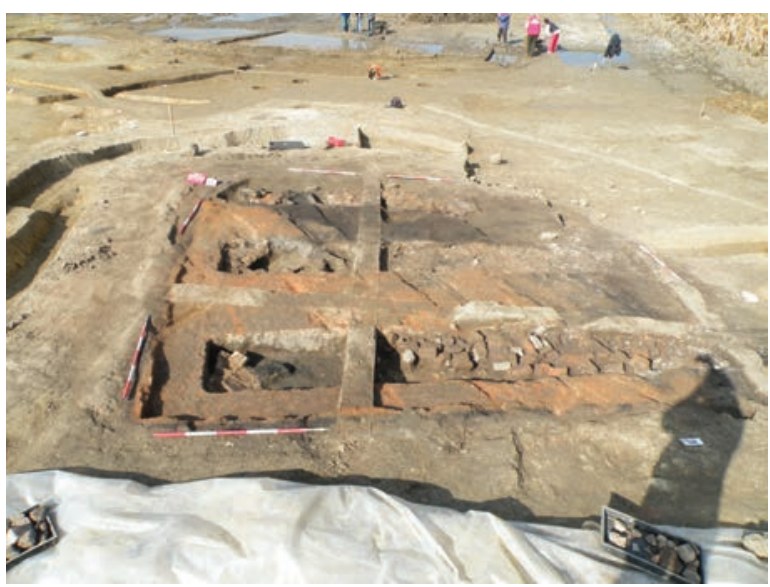

10. ábra. A téglaégető délről fotózva

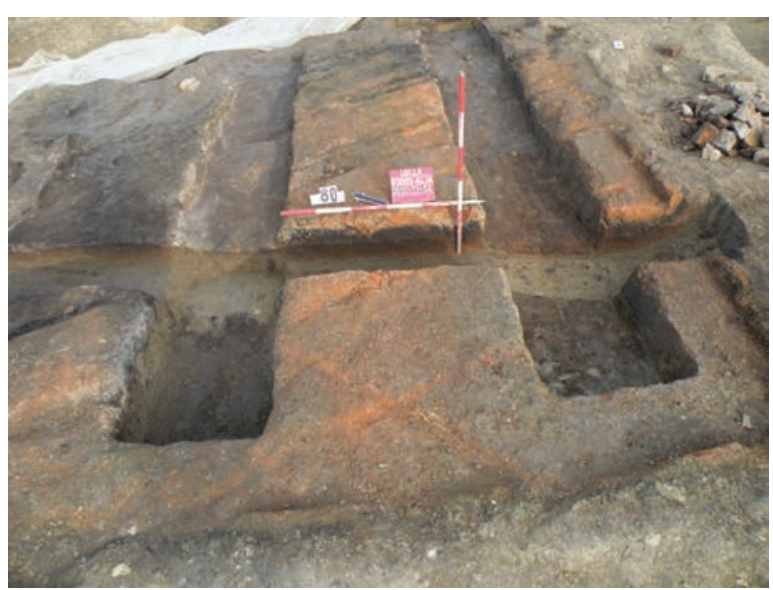

11. ábra. A téglaégető kemence átmetszett maradványai

A kemencében megtalált kiégetett téglák vizsgálata jelentősen módosította az objektum korára vonatkozó elképzeléseinket. A 28,5-30×14-14,5×6-6,5 centiméteres téglákon $\mathrm{Cl}$ jelü domború bélyeg volt (13. ábra). Kelemen Éva szerint a bélyeges téglák a 16. század második felétől bécsi mintára terjednek el, a 18. század második felében a domború feliratok homorúknak adják át helyüket.22 Mivel számos évszámmal ellátott domború tégla van, a 19. században egyértelmű továbbélésük. Ezt elfogadva kemencénket a 16. század közepe és a 19. század közötti időszakra keltezhetnénk. A korszak kezdete a török hódoltság kora. A terület a század közepére török kézre kerül, egy darabig még szerepel a lajstromokban, de 1609ben már pusztaként említették. ${ }^{23}$ Valószínűbb lehetőség, hogy a téglaégető a hódoltság utáni újjátelepüléshez köthető. A török korban elpusztult a falu területe, amely nem népesült be rögtön a felszabadulás után. Úgy tűnik, először a kemence lelőhelyétől 1,5-2 kilométerre, a mai Jabapuszta mellett építkeztek. Az első katonai felmérésen erre jelölik „Lujat”, a másodikon Jabap(uszta) és Lullap(uszta) házait. Lullapuszta a Lengyel, illetve a Mérey család, Jabapuszta a tihanyi apátság birtoka volt (14. ábra). ${ }^{24}$ A korai épületek és az edényégető helyét a széles árterű Jaba-patak kötötte össze, a téglák szállítása jól megoldható volt. A település későbbi telepítések során került délebbre, az egykori falu mellé. A 19. században szinte elnéptelenedő lakossága a 20. század eleji telepítések során szaporodott fel, utóbbihoz kapcsolódóan, 1907-1913 




12. ábra. A téglaégető déli fütőcsatornája a benne talált téglákkal

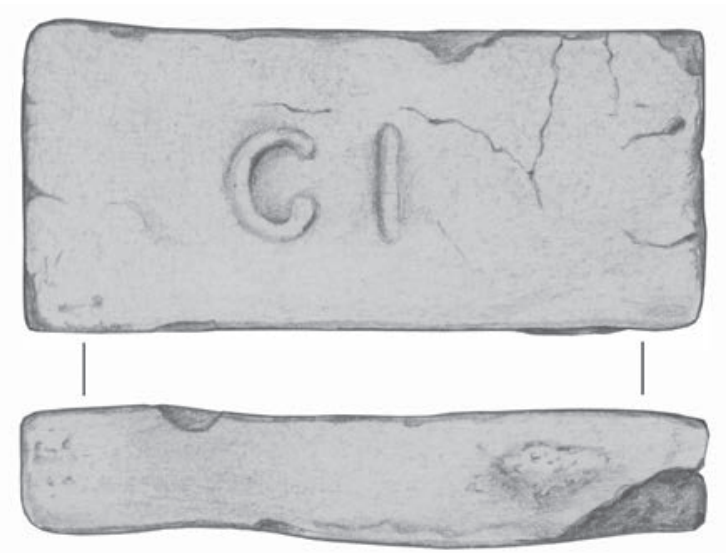

13. ábra. A téglaégetőben talált tégla között 3 téglaégető működött Lullapusztán. ${ }^{25}$ Utóbbiakhoz nem kapcsolnám a feltárt kemencét, a benne talált téglák korábbiak lehetnek. Valószínűleg a 18. századi újjáépítéskor használták, ugyanakkor a téglákon lévő monogramot nem tudom az ismert birtokosokhoz kötni.

A szóba jöhető korszakból kevés téglaégetőt ismerünk. Budapesten a Zsigmond tér 5-7. szám alatt két 17. századi kemence részlete került feltárásra. A földbe ásott kemencék közül az egyiknek épített rostélya lehetett, a másik a lullaival megegyező típusba is tartozhatott. ${ }^{26}$ Lőcsén egy földbeásott, nagyméretű $(9,9 \times 8,3$ méteres), négycsatornás kemence került elő, amelyet a 16-17. században használtak. ${ }^{27}$ Ennél is fiatalabb téglaégetőt tártak fel Izsán, az igen nagyméretű $(14,4 \times 11,4$ méteres) földbe mélyített kemencét a 19. század 2. fele és a 20 század 1. fele közé keltezték. ${ }^{28}$ Ebből az időszakból már számos leírással, rajzzal, fotóval is rendelkezünk, amelyek a téglaégetés folyamatát, a téglaégetők formáját ismertetik. ${ }^{29}$ A példák alapján a kemencék általában a földfelszínre épültek vagy csak kissé mélyedtek az altalajba, sokszor csak a talajt egyengették el az építésük előtt. Az ilyen objektumoknak régészeti nyoma így általában nem maradt, a középkori használatukra is csak következtethetünk. A Lullán talált példány is viszonylag sekélyen lehetett beásva, de a tüzelőcsatornáit és padkáit a talajszint alatt alakították ki, így régészetileg megtalálható volt.

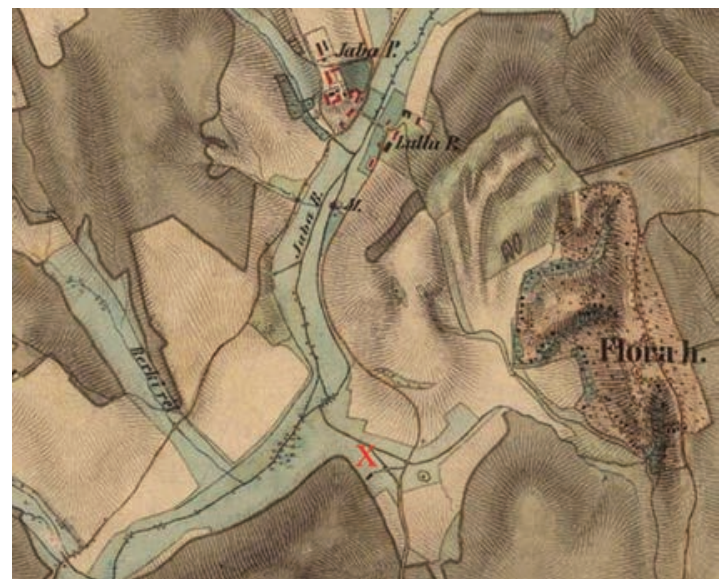

14. ábra. A téglaégető kemence helye a 2. katonai felmérésen

25 NAGY 2005, 174-176.

26 KÁRPÁTI 2003; ЈАКAB 2011, 136-137.

27 JAVORSKY 1983, 106, 271, 54. kép; Čunny 2009, 123, 140, VII. tábla, 143.

28 ČURNY - HANULIAK - KuZMA 2008; ČURNY 2009.

29 JАКАВ 2005; VALTER 1987, 149-152. 


\section{Összefoglalás}

Somogy megyéből egy középkori (feltehetően a 13-14. század fordulójára keltezhető) és egy újkori (valószínűleg 18-19. századi, esetleg a 20. század elejéről való) téglaégető kemencét ismerünk. Figyelemre méltó a szerkezeti hasonlóságuk, ismét megfigyelhetô, hogy gyakorlatilag az Árpád-kortól a 19. századig hasonló módszerrel gyártották a téglákat. Amennyire a kevés publikált kemence alapján megállapítható, idővel talán nőtt a kemencék átlagos mérete, da a falusi környezetben talált kemencék nem lettek bonyolultabbak. Esetünkben az évszázadokkal korábbi Nagyatád-bódvicai kemence valamivel jobb konstrukciónak tűnik. Ugyan kisebb, de jobban a földbe mélyedhetett, padkáit téglából építették meg.

A két példa jól mutatja a téglaégető kemencék datálási nehézségét is. Az objektumok általában leletszegények, a talált leletanyag is sokszor másodlagos helyzetű. Esetünkben a kemencékben maradt téglákra támaszkodva próbáltuk korukat meghatározni. A nagyatád-bódvicai kemencénél a közelben feltárt és viszonylag jól keltezhető templom alapozásának a téglaégetőben találtakkal látszólag megegyező téglái jelentettek segítséget. A lullai kemencéknél a feliratos téglák utalnak az objektum viszonylagos fiatalságára.

\section{Two brick kilns from Somogy county}

\section{ISTVÁN MOLNÁR}

The study describes two brick burning kilns from Somogy county. A part of a brick burning kiln was excavated at Nagyatád-Bódvica in 2002 by Csilla Aradi. The kiln was deepened into the soil at least $120 \mathrm{~cm}$ with one side $480 \mathrm{~cm}$ long and it had four heating plackets. The bottom of the kiln was horizontal, deeper firing chanels and higher benches were not formed. The benches were built from raw bricks. Inverse bricks were placed on the top of a sparcely set row of bricks below the raw bricks. The remains of the medieval church of Boda village was excavated some $100 \mathrm{~m}$ from the kiln. The bricks discovered in the foundation of the church match with the ones found in the kiln, so it seems that the bricks were manifactured for the building of the church. The church was erected at the turn of the 13-14 th centuries, which dates the kiln to the same period.

We excavated the remains of a kiln at Lulla-Büdösalja site. The kiln was digged into the ground and was about $550 \times 660 \mathrm{~cm}$ in extension. It had three $70 \mathrm{~cm}$ wide firing chanels, while the benches made from subsoil were $20 \mathrm{~cm}$ high. On some of the bricks found in the kiln convex $\mathrm{Cl}$ monograms were found. We can date the kiln to the $18-19^{\text {th }}$ centuries. 


\section{Irodalom}

M. Aradi 2003 M. Aradi Csilla A bódvicai rotunda. Múemlékvédelem XLVII/4. 263-266.

M. ARADI 2016 M. Aradi Csilla: Somogy megye Árpád-kori és középkori egyházszervezetének rekonstrukciója. Kaposvár, 2016.

ČURny - Hanuliak - Kuzma 2008 Čurny, Marian - Hanuliak, Milan - Kuzma, Ivan: Tehliarska pec z lže pri Komarne. Archeologia technica 19. 83-103.

ČURNY 2009 Čurny, Marian: Archeologicke doklady vyroby tehiel na Spiši. Vychodoslovensky pravek IX. 121-144.

ČURnY - Romsauer 2009 Čurny, Marian - Romsauer, Peter: Stredoveka tehelna v Chotine (Eine mittelalterliche Ziegelei in Chotin). Archaeologia Historica 34. 523-540.

GereVICH 1983 GereVICH LAszló: The royal court (curia) provost residendence and the village at Dömös. Acta Archaeologica 35/3-4. 385-409.

JАКАВ 2005 Jakab Attila: A téglavetésröl. Jósa András Múzeum Évkönyve 47. 345-365.

JAKAB 2007 Jakab Attila:Téglaégető kemencék az írott forrásokban. Jósa András Múzeum Évkönyve 49. 325-332.

JAKAB 2011 Jakab Attila: Téglaégető kemencék a középkori Magyarország területén. Jósa András Múzeum Évkönyve 53. $131-160$.

JANKovich 1976 Jankovich B. Dénes: Adatok a Rinya-völgy középkori településtörténetéhez. Somogy Megye Múltjából 7. $3-37$.

JAVORSKY 1983 Javorsky, Frantisek: Notgrabungen und Geländebehungen der Forshungsexpedition Spis. Archeologicke vyskumi a nalezy na Slovensku v roku 1983. 104-108.

KÁRPÁTI 2003 Kárpáti Zoltán: Budapest II Zsigmond tér 5-7. In: Kisfaludi Júlia (szerk.): Régészeti Kutatások Magyarországon 2000. Budapest, 2003. 108.

KELEMEN 2001 Kelemen Éva: A téglakészítés régi mestersége. Tisicum XII. 221-227.

LŐRINCZY 1984 Lőrinczy Gábor: Árpád-kori téglaégető kemencék Tiszalök-Kövestelken. In: Gömöri János (szerk.): Iparrégészet II: Iparrégészeti és archaeometriai kutatások Magyarországon. Veszprém, 1984. 155-163.

LŐRINCZY 1992 Lőrinczy Gábor: Középkori téglaégető kemencék Csongrádról és Békéscsabáról. Móra Ferenc Múzeum Évkönyve 1989-90/1. (1992) 159-180.

MolnÁR - Sipos 2013 Molnár István - Sipos Carmen: Lulla, Büdösalja. In: Honti Szilvia - Hajdú Ádám Dávid - Költő László Molnár István - Németh Péter Gergely - Sipos Carmen: Régészeti feltárások Somogy megyében 2007-2011 között. A Kaposvári Rippl-Rónai Múzeum Közleményei 1. 118-119.

Mıkıós 2002 Miklós Zsuzsa: Dombóvár, Szigeterdő középkori téglaégető. In: Marton Erzsébet - Kisfaludi Júlia (szerk.): Régészeti Kutatások Magyarországon 1999. Budapest, 2002. 155-163.

NAGY 2005 Nagy Ernő: Lulla község története. In: Bertalan Béla (szerk.): Tabi kilátó 2004-2005. Helytörténeti olvasókönyv. Tab, 2005. 135-198.

OLÁH - KelE - Ács 2010 Oláh István - Kele Sándor - Ács Zsófia: Természetes és mesterséges eredetű építőanyagok PaksCseresznyés (M6 autópálya TO18) régészeti lelőhelyről. Évkönyv és jelentés a Kulturális Örökségvédelmi Szakszolgálat 2008. évi feltárásairól. Budapest, 2010. 197-248.

VALTER 1987 Valter Ilona: Az őriszentpéteri középkori téglaégető kemence. Communicationes Archaeologicae Hungariae 7. 139-155.

VALTER 1989 Valter Ilona: Öriszentpéter. Középkori téglaégető kemence. Tájak Korok Múzeumok Kiskönyvtára 334. Budapest, 1989.

Vızı 2014 Vizi Márta: Késő középkori téglaégető kemencék Bátaszék-Leperdpusztán. A Wosinsky Mór Megyei Múzeum Évkönyve XXXVI. 289-322. 
